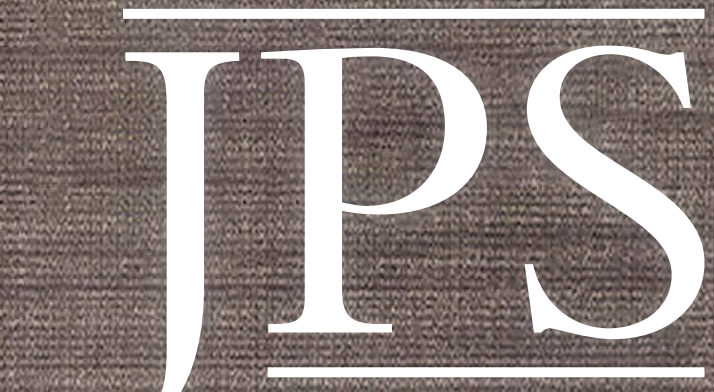

The Journal of the Polynesian Society
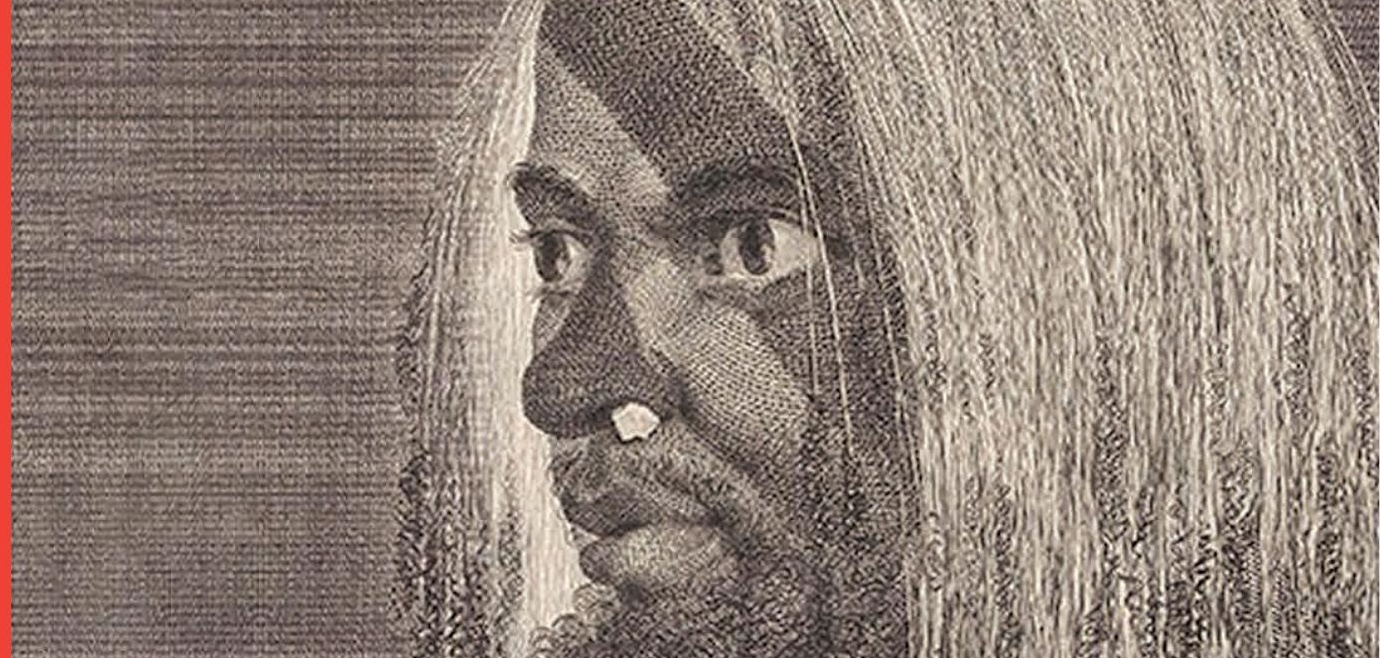
잔. (1) $-12 x^{2}(5)$

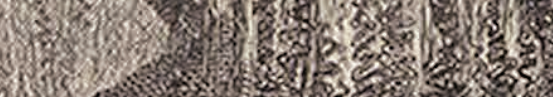
4 in

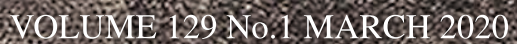




\title{
A LARGE TROLLING LURE SHANK FROM AHUAHU GREAT MERCURY ISLAND, NEW ZEALAND
}

\author{
LOUISE FUREY \\ Auckland War Memorial Museum \\ REBECCA PHILLIPPS \\ University of Auckland \\ JOSHUA EMMITT \\ University of Auckland \\ ANDREW MCALISTER \\ University of Auckland \\ SIMON HOLDAWAY \\ University of Auckland
}

\begin{abstract}
Large stone trolling lure shanks, greater than $100 \mathrm{~mm}$, are rare and stylistically associated with the early period of Māori occupation of Aotearoa New Zealand. The triangular-sectioned shank is distinctive and reminiscent of Polynesian forms. The 2016 find during excavations at T10/360 at Waitapu in Coralie Bay, Ahuahu Great Mercury Island, is the first to be recovered in an archaeological context and only the third large shank attributed to the North Island. Moreover, the shank is the largest complete example known. Radiocarbon dates from contexts in direct association with the shank indicate deposition in the early 15 th century, slightly later than other sites such as Wairau Bar and Shag River Mouth where similar shanks have been found. A comparative analysis of the attributes of all 28 shanks in New Zealand museum collections indicates no regional patterns are evident. We review the context in which the Ahuahu shank was found, and its importance, along with the other items recovered, for the interpretation of the Waitapu occupation. We also consider the various reported interpretations of large trolling shanks and, based on Polynesian examples where symbolism and function are discussed, suggest large shanks were not used directly in fishing but had a fishing-related role.
\end{abstract}

Keywords: Māori material culture, serpentinite artefacts, trolling lure shank, New Zealand archaeology, Ahuahu Great Mercury Island

Large stone trolling lure shanks, stylistically associated with the early period of Māori occupation of Aotearoa New Zealand, are rare. The November 2016 find during excavations at T10/360 at Waitapu in Coralie Bay, Ahuahu Great Mercury Island (Fig. 1) (Furey et al. 2017), is the first to be recovered in an 


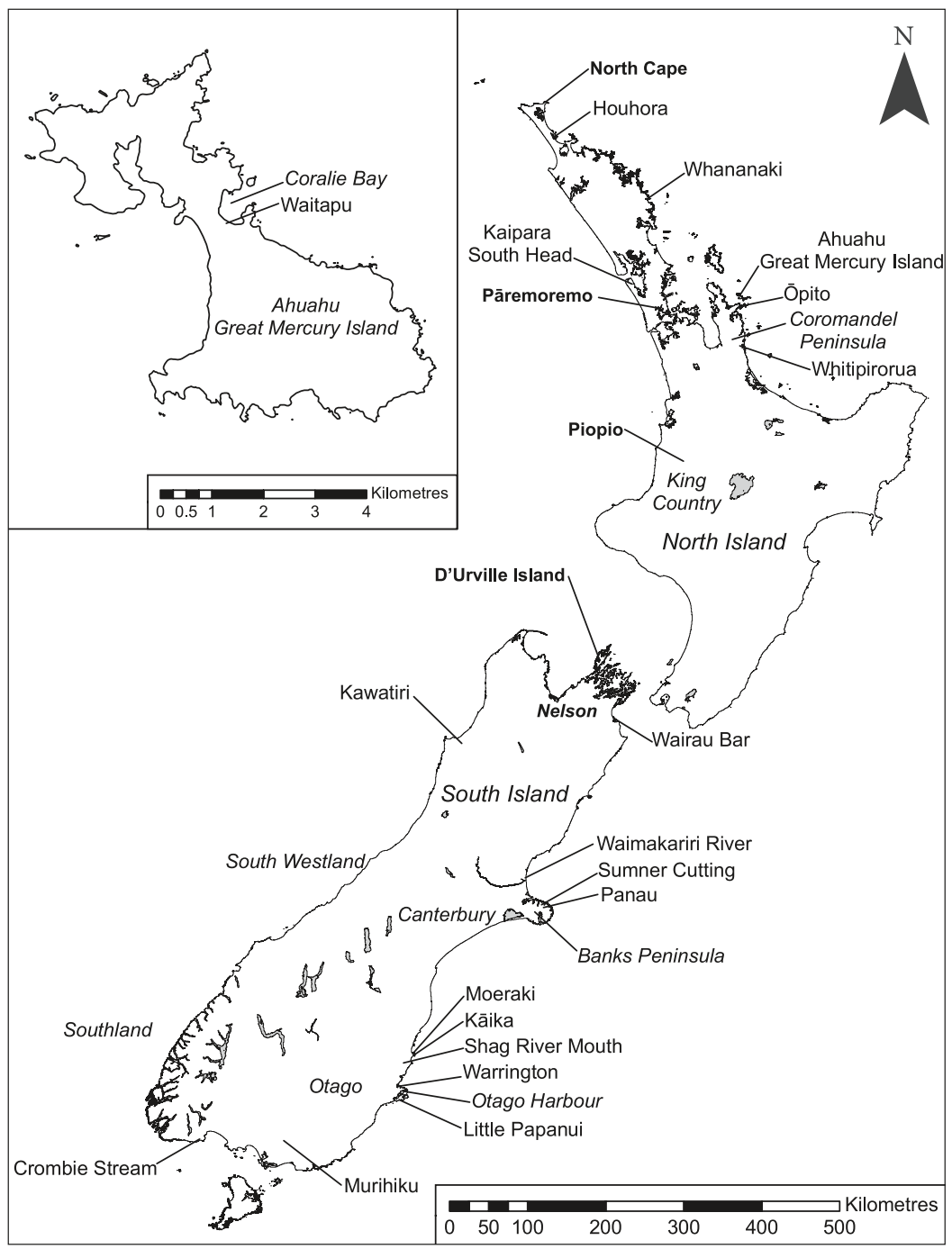

Figure 1. Places mentioned in the text, with an inset of Ahuahu Great Mercury Island. Serpentinite sources are identified in bold. 
archaeological context and only the third known large shank attributed to the North Island. Moreover, the shank is the largest complete example known. Here we provide commentary on similar items in New Zealand museum collections, review the context in which the shank (identified as 174914 in the project database) was found and discuss radiocarbon determinations from T10/360. We also consider the function of large trolling shanks and the importance of this one for interpretation of the Waitapu occupation.

\section{COMPARABLE NEW ZEALAND TROLLING LURE SHANKS}

Trolling lure fish hooks, comprising a bone point lashed to one end of a stone or bone shank and a groove or perforation at the other end for attaching a line, were pulled through the water to attract pelagic fish. Most trolling lure shanks in museum collections or recovered from excavations are small, of oval cross-section and grooved for line attachment. Shanks from the initial colonisation period are more varied in form and include those with perforations and a triangular cross-section, in addition to more common oval and rectangular forms made from stone, bone and less frequently, shell (Davidson 1979; Duff 1977; Furey 1990, 2002; Teviotdale 1929). Hamilton (1908: 22) called the trolling hooks manea, as opposed to the generic $p \bar{a}$ now used, and large fish hooks whatu, which had karakia 'Māori incantations and prayers' recited over them at appropriate times to ensure a plentiful catch. However, Hamilton did not specify whether these large fish hooks were also functional and used to catch fish.

Skinner (1942: 257-58) observed the resemblance of triangular-sectioned trolling lure shanks from chronologically early southern New Zealand sites to bonito lures of Polynesia, particularly those examples with greatest depth at the perforation and, in profile, a pronounced upper surface curvature from proximal to distal end. The early age of the sites was based on the style of associated material culture and presence of extinct birds.

Museums were canvassed for large-sized objects of similar form, called shanks for want of something to call them because that is what they resemble, but function cannot be assumed from the shape. There are only a few excavated early archaeological assemblages with trolling lure shanks, indicating the rarity of excavated shanks of any size and of large shanks in particular. The assemblage from Wairau Bar, the most well known of early settlement sites, is an exception, and with 248 shanks is the largest assemblage from any site (Duff 1977; Findlater 2011). A large area of the site was, however, dug over using non-archaeological techniques to obtain the quantity of material culture recovered. Kawatiri Buller River Mouth produced 57 shanks fashioned from stone (Findlater 2011). The count at both sites includes fragments and items at all stages of manufacture. While the 
shanks from Kawatiri are made exclusively from stone, those from Wairau Bar are fashioned from stone (189), bone (5) and shell (54). Around 50\% of shanks from Kawatiri and 73\% from Wairau Bar are triangular in crosssection (Findlater 2011: 119, 120). Kawatiri shanks are all less than $80 \mathrm{~mm}$ in length, and while the largest complete shank from Wairau had a length of $102 \mathrm{~mm}$, and one mid-section fragment is also likely to have come from a large shank (Duff 1977: 390), the remainder of the 248 are less than $80 \mathrm{~mm}$ in length, indicating that large shanks were not the norm.

Based on size distributions from the two large archaeological assemblages, a minimum size of $100 \mathrm{~mm}$ was set as the criterion for distinguishing large shanks in museum collections. Suitable lures were measured, even when only a fragment was present. The presence of notching on the edges, flaking, and point seat modifications and the presence or absence of projecting fins or incised lines were recorded, including for those examples illustrated in the literature but not relocated. There are 28 complete or fragmentary shanks in total, but not all have a known provenance (Table 1 and Fig. 1). Five fully ground examples lack perforations and a point seat area. Dimensions for the shanks in private or museum collections that were not sighted were obtained from published descriptions.

Ten shanks are attributed to Shag River Mouth in Otago (Anderson and Gumbley 1996: 148; Skinner 1942; Teviotdale 1929). Other Otago examples are from Moeraki, Kāika near Moeraki, and Warrington, and a recently found shank is from Little Papanui (Phillip Latham, University of Otago, pers. comm., 2017). Elsdon Best's (1929: 35-36) provenance of the Moeraki shank was later disputed, without elaboration, by Roger Duff (1977: 207), who claimed it was collected by Augustus Hamilton from Shag River Mouth. There are two examples attributed to the Southland region, locations unknown. Further north in the South Island are shanks from Sumner Cutting in Christchurch, Panau on Banks Peninsula, Waimakariri River Mouth and one in a private collection (C. Griffiths) with artefacts mainly from the South Canterbury and North Otago areas. Two examples are from Wairau Bar. Only three shanks more than $100 \mathrm{~mm}$ are known from the North Island: Whananaki north of Whangārei, Kaipara South Head and the lure shank described here from Ahuahu. There are two with no provenance whatsoever.

An item in the Southland Museum from Crombie Stream on the south coast of Fiordland is termed a trolling lure shank in the museum catalogue and fits the size criterion, but instead of a point seat area at the distal end it has grooves on the ventral surface for lashing. It also has circular depressions drilled from both sides which do not meet, and bosses at the ventral margin behind the depressions. While this item might be similar to others described here, given it is made from bowenite, which is brittle, it is interpreted as a pendant in the style of a trolling lure shank and therefore is not included. 
One of the Southland-attributed items has the distinctive minnow lure shape but the distal end is broken across a bilateral perforation. Although referred to as having a unique method of point attachment (Skinner 1942: 267), it is more likely to have been reworked and subsequently broken through the perforation.

Approximately half of the shanks described above are made from serpentinite. Stone identification of the remaining items, mostly from Shag River Mouth, has not been confirmed, although Teviotdale (1929: 280) describes the materials as red argillite, basalt, mudstone and schist. The Little Papanui shank is "red claystone" from the Otago Harbour area (Phillip Latham, pers. comm., 2017). Unfortunately, raw material is not identified in a consistent way for most shanks, and during a visit to Otago Museum in 2017, only casts of some were available for measurement. The Southland Museum item is described in the catalogue as "dark grey baked argillite". Canterbury Museum shanks from Sumner, Wairau Bar, Kāika and Shag River Mouth are of black serpentinite, as are the North Island Kaipara and Whananaki shanks.

Skinner (1942) asserted that shanks increased in size from Banks Peninsula south to Otago on the basis that none have been found further north. Duff reiterated Skinner's observation, but since 1956 when the first edition of Duff (1977) was published, more shanks have been accessioned into museum collections and the generalisation of large shanks being exclusively from southern South Island no longer holds true. Duff (1977: 207) reasoned that the large size would prevent the shank and hook being swallowed and the line severed by the sharp teeth of barracouta (Thyrsites atun), the dominant fish catch in the south. Following this reasoning, large shanks should occur frequently in museum and excavated southern assemblages. However, Anderson (1981:281-82) argued the specialised wooden lures and bone points which also occur in early southern sites were designed to catch barracouta, and instead proposed that the large shanks were pendants, although there is no evidence to support this interpretation other than they have perforations which might have been used for suspension.

Of the large lure shanks 17 are complete and range in length from 102 to $218 \mathrm{~mm}$. The remaining 11 are fragments, predominantly the distinctive proximal end, but there is a mid-section fragment from Wairau Bar, and one represented only by the distal end from Shag River Mouth. Teviotdale (1929) referred to an example in Southland Museum that measured $125 \mathrm{~mm}$ in length and is possibly the object illustrated by Hamilton (1908: 23, fig. 10 , top left). It has a distinctive continuation of the fins over the dorsal ridge, similar to the example $(90 \mathrm{~mm})$ in Southland Museum. The breaks are similar in shape and are likely to be the same object despite the difference in reported lengths. 

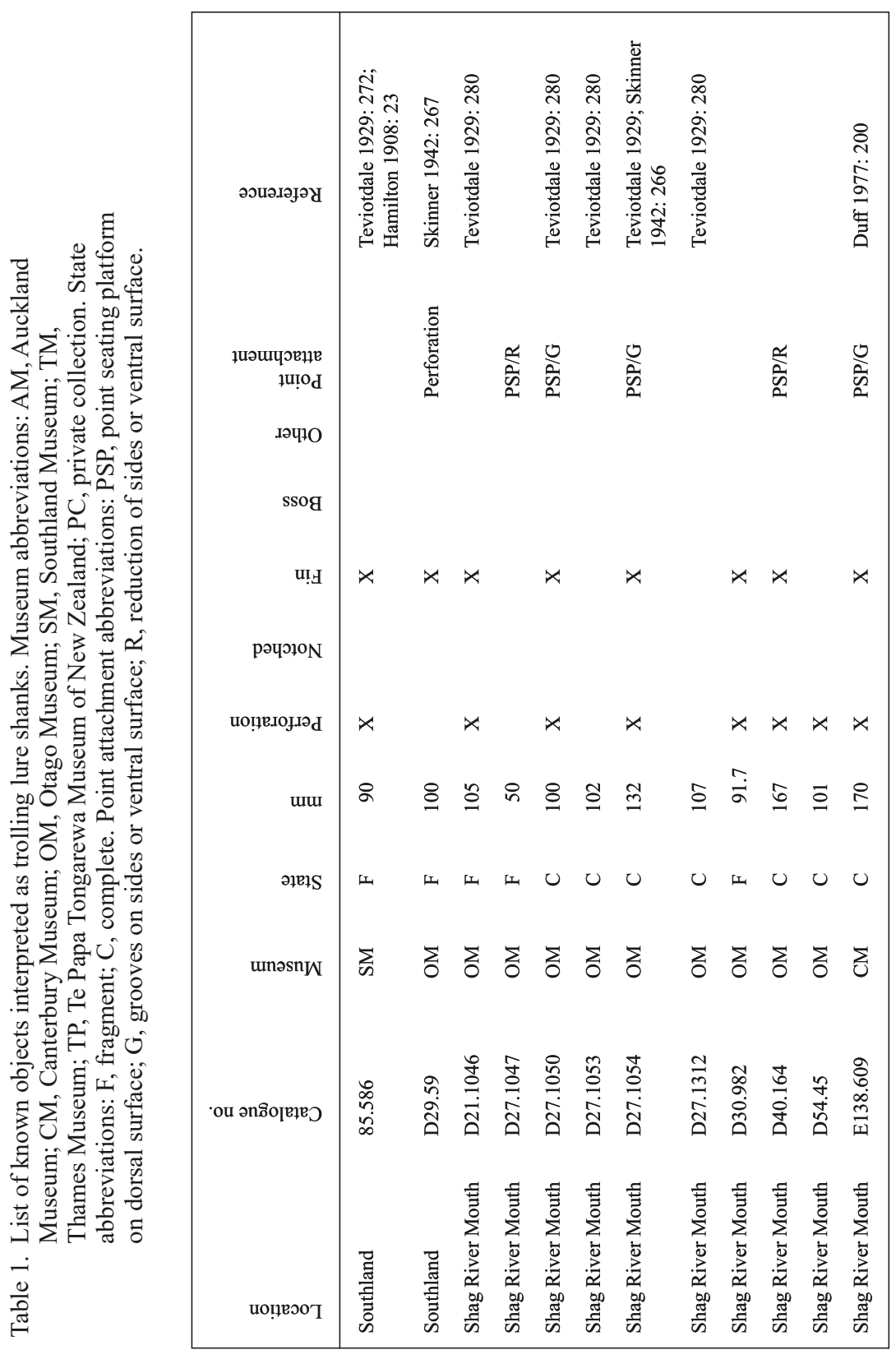


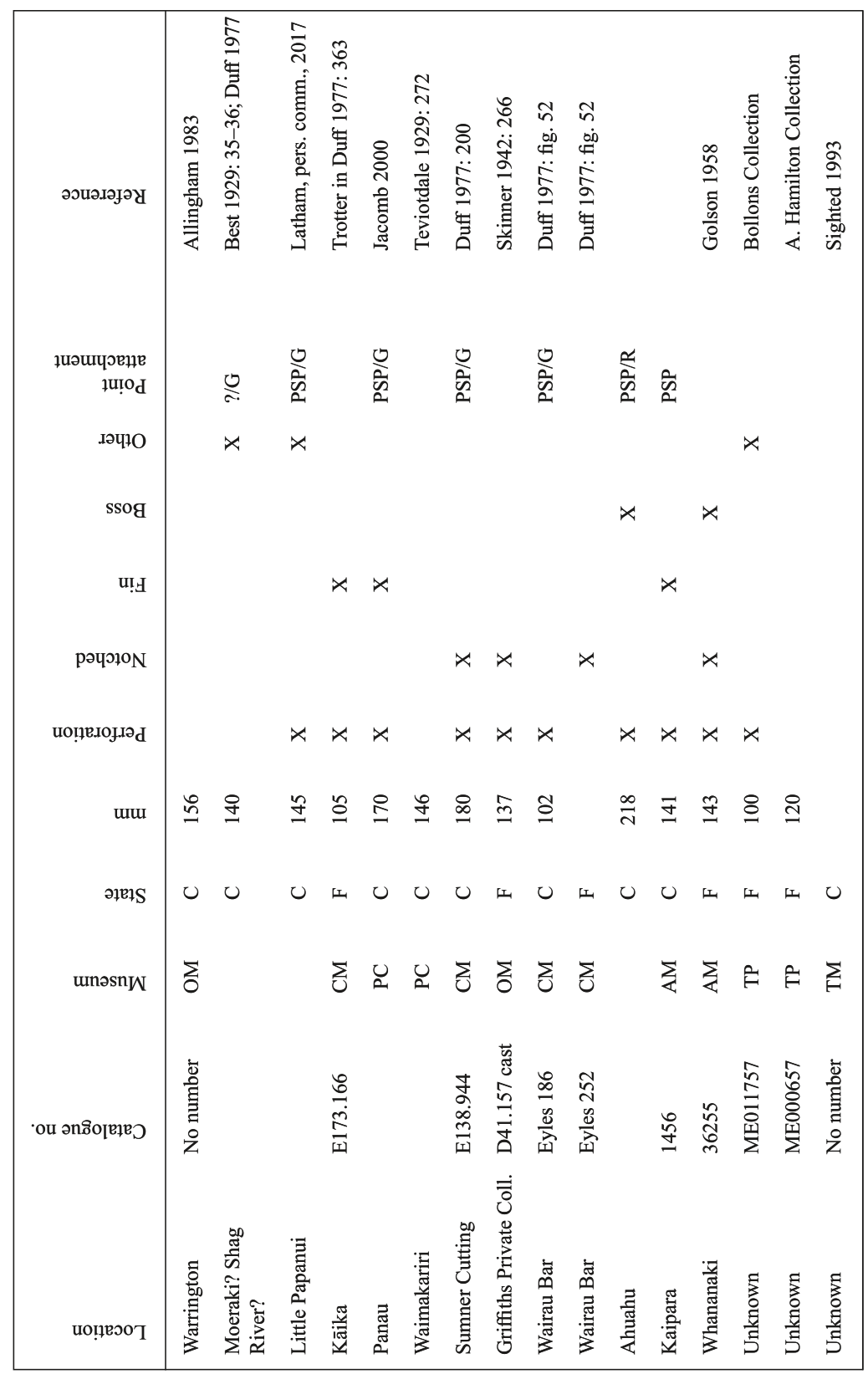


Of the complete examples, none are close in length to the Ahuahu shank, with the next longest being nearly $40 \mathrm{~mm}$ shorter. Measurement of the forward edge of the perforation to the nose, with the width and depth measured at the perforations, proved the best indication of length when comparing complete and incomplete items: the Whananaki and Shag River Mouth fragments may be close in size to the Ahuahu shank. The Kāika fragment in Canterbury Museum may have come from a larger shank, although the length from perforation to the proximal end is disproportionately long compared to other examples, potentially providing an overestimate of overall length relative to nose length. The five complete items without perforation and point seat are 101-156 $\mathrm{mm}$. The three from Shag River Mouth are all close in size, with that from Little Papanui being the largest. The fragment of unknown provenance in Te Papa may, if complete, have exceeded the largest measurement.

While all the large shanks have a greater than $100 \mathrm{~mm}$ length in common and a triangular cross-section, other attributes such as notches, bosses and fin or gill-like projections may or may not be present. Skinner (1942: 258) described the shallow projections from the ventral edges to behind the perforations as resembling a "shark-like mouth" when viewed from the side (an unlikely association when the shank is intended to mimic a small fish), and the claim of it being a Murihiku (southern South Island) feature is refuted by later finds from other areas. Eleven shanks have fins, including that from Kaipara, and on the Southland Museum example these extend up the sides and over the dorsal ridge. Bosses or lugs, small circular projections below the perforation, are present on two shanks (Ahuahu and Whananaki).

Notching is evident on four shanks: Whananaki and Sumner where three edges are notched from the proximal end, Wairau Bar mid-section where the two ventral edges are notched, and the Griffiths Collection item from an unknown South Island location, notched on the dorsal ridge only. The nose of the Little Papanui shank is reduced in width and depth from forward of the perforations, as is the example from Panau. The unsighted shank from Moeraki or Shag River Mouth (Best 1929: 35-36; Duff 1977: 207) is different in having two criss-crossed incised lines on the ventral surface close to the proximal end. A variation of incised lines is demonstrated in a fragment with an incised line on the right side, angling back and down to the ventral edge then continuing onto the ventral surface (Te Papa Bollons Collection ME011757, provenance unknown). The Whananaki lure also has an incised line near the ventral edge on each side, from the nose to approximately halfway to the perforation. None of the attributes described here appear to be confined to any one region.

All complete examples with perforations have a flattened point seat platform on the dorsal surface, which can be narrow, or broad in the case 
of the Ahuahu shank. On the ventral surface there are either three or four grooves to confine the fibre lashing, or a broad reduced area with a lip or flange at the distal end. The Kaipara shank is unique in having a point seat platform but no ventral modification. Shank shapes without perforation (three: from Shag River Mouth, from Warrington and of unknown provenance) also have no point seat area. In functional trolling lures these examples would be called incomplete or unfinished, but this interpretation cannot be assumed for the large shanks.

There are also differences in the longitudinal profile, with shanks having either a straight profile where the upper and lower edges are parallel, or a deeper profile at the perforations reducing in a concave curve on the dorsal ridge to the point seating area. This style closely resembles the East Polynesian bonito shank made from pearl-shell in which the thicker shell depth at the hinge forms the proximal end of the shank. The pearlshell examples, however, are considerably smaller in length and overall proportions to the shanks discussed here. Only four are of this form, none from the North Island.

Breakage occurs most commonly behind the perforations, or mid-body, with a single example from Shag River Mouth breaking towards the distal end. The Southland example has snapped off through the perforation at the distal end, but as discussed earlier this is likely to have occurred later. The notched Wairau Bar fragment is a mid-section with transverse breaks at both ends. Pieces of broken shank may have been reworked, particularly when made from serpentinite, which was also used for pendants, small and large reels and smaller trolling lure shanks.

Trolling lure points are usually made of bone or ivory rather than stone, but none of these large shanks were recovered with an associated point. Teviotdale (1929) did, however, find what he considered to be an associated shank and point at Shag River Mouth, measuring $88 \mathrm{~mm}$ and $51 \mathrm{~mm}$ respectively, which suggests that if this ratio is the norm, points for large trolling lure shanks would be very distinctive. However, the point does seem disproportionately large for the shank length, and if this ratio was applied to the Ahuahu shank, the point would be an excessively large $126 \mathrm{~mm}$. There are no reported examples of serpentinite points from excavated assemblages or museum collections. However, there is a surface find of what is interpreted as a serpentinite point, with the distal end broken off, from a bay at the south end of Ahuahu. If complete this point would have had a large base, certainly of a comparable size to the point seat area on the Ahuahu shank. It is estimated that if complete the lure point would be approximately $70 \mathrm{~mm}$ length. While these two objects were not in direct association, the fact that two extremely rare objects of same material and colour were found on the island, in chronologically early contexts, seems a huge coincidence, and 
there is a strong possibility they were, at one time, together, or brought to the island together. The shank has polish from the fibre lashings at the distal end, and so did, at some stage in its life, have a point attached.

All shanks are ground. Each was examined for evidence of manufacture including depressions or irregularities in the surface that might suggest remnants of flake scars and initial shaping by flaking. No such indications were found, and it is likely that the stone was worked into shape by sawing, a method employed in the manufacture of other stone tool types such as роипати 'nephrite', and observed on many serpentinite artefacts in the Wairau Bar collection. Grinding with abrasive stone was then used to produce the finished surface.

Trolling lure shanks have been recovered from a number of archaeological excavations on Coromandel Peninsula, but cross-sections tend to be round or oval (Davidson 1979) and bone or petrified wood is the preferred material. Triangular-sectioned trolling lure shanks from the peninsula are rare, and museum collections suggest they were also rare in Northland. The only other known Coromandel example, also in serpentinite and attributed to Ōpito, is $69 \mathrm{~mm}$ in length (Bollons Collection, Te Papa; Duff 1977: 389). Shanks attributed to Coromandel Peninsula, regardless of material or cross-section, are generally less than $70 \mathrm{~mm}$ in length. The exception is a broken bone shank from Whitipirorua (Onemana) with a length greater than $110 \mathrm{~mm}(46453$, Auckland Museum collection; Furey 1990). The serpentinite triangularsectioned shank of unknown provenance in Thames Museum may or may not have been found on Coromandel Peninsula, and the donor's family was unable to provide further information.

\section{Summary}

There are 28 items interpreted as large shanks (length $>100 \mathrm{~mm}$ ) in museum collections and/or described in the literature. While there are many archaeologically known examples of lure shanks, the majority do not exceed $80 \mathrm{~mm}$ in length, and few of these have triangular cross-sections. Large stone lure shanks are therefore rare and never commonly manufactured. The range of additional attributes, beyond size, cross-section and material, indicates little in the way of geographic pattern.

Unfortunately, because of the way most the shanks were found, it is difficult to draw inferences from their discovery contexts, except to note that large numbers of other types of artefacts were found at Shag River Mouth and Wairau Bar. Ahuahu is the exception, but there is little to be deduced from context. No structures were found, and little bone, as soil conditions generally on the site were not conducive to good bone preservation (Ash 2017). 


\section{DESCRIPTION OF THE AHUAHU SHANK}

The trolling lure shank from Ahuahu (Fig. 2) is $218 \mathrm{~mm}$ in length, a maximum of $38 \mathrm{~mm}$ wide and with a maximum depth of $34 \mathrm{~mm}$ immediately behind the perforations. It is triangular in cross-section, with the greatest depth at the perforations, tapering to a point at the proximal end where several small chips of stone have detached. The shank is widest slightly behind the perforations, which are placed close to the dorsal ridge. The perforations are drilled bilaterally from each side and each hole angles slightly downwards. The sides of the holes are straight, suggesting use of a non-tapered drill point. The hole on the right side (viewed from top down, proximal end uppermost) is not circular and has two shallow scars on the lower edges that may indicate earlier attempts at initiating the hole. The edges of both holes are sharp and have no macroscopic wear visible.

On each side is a shallow $(4 \times 3 \times 1 \mathrm{~mm})$ round lug or "boss" near the ventral edge below the perforation. The bosses protrude by about $1 \mathrm{~mm}$ and have ground edges, but the broad upper surfaces are not ground. At the distal end, the dorsal ridge is shaped to a flattened platform measuring $26 \mathrm{~mm}$ length and $15 \mathrm{~mm}$ width where a point might be seated. There is a reduced width on the ventral edges, likely for the purpose of confining the fibre lashing, and the distal end also has a raised lip or flange $2 \mathrm{~mm}$ high which extends around to the edges of the seating platform and is possibly for the same purpose. On the ventral surface, the shank is laterally convex, and when sitting on a flat surface there is a slight longitudinal curve so that the proximal and distal ends are slightly elevated.

Surfaces are finely ground with shallow longitudinal scratches from the shaping and grinding process. These are most pronounced on the left side from the perforation to the point seating area. Less extensive scratching is present on the right side, again from behind the perforation to the point platform. On the ventral surface the scratches also commence level with the perforations but only extend $116 \mathrm{~mm}$ along the sides and not as far as the point seat area. Deep striations are present on the dorsal ridge from the seating platform to an area of hammer dressing (discussed below). Pitting on the surface of the stone on the left and right sides (but not the ventral surface) is possibly due to hammer dressing but may also result from softer minerals weathering out. The dorsal ridge has hammer dressing which commences $11 \mathrm{~mm}$ forward of the perforations and continues for $81 \mathrm{~mm}$ but shows no flaking. The hammer dressing on the dorsal ridge was carried out post-grinding; however, under magnification $(10 \times)$ there is polish or faint wear over the scars. Given the dune environment in which the shank was found (see below), the polish may reflect sand abrasion. There are vertical striations on the edges of the point seat 

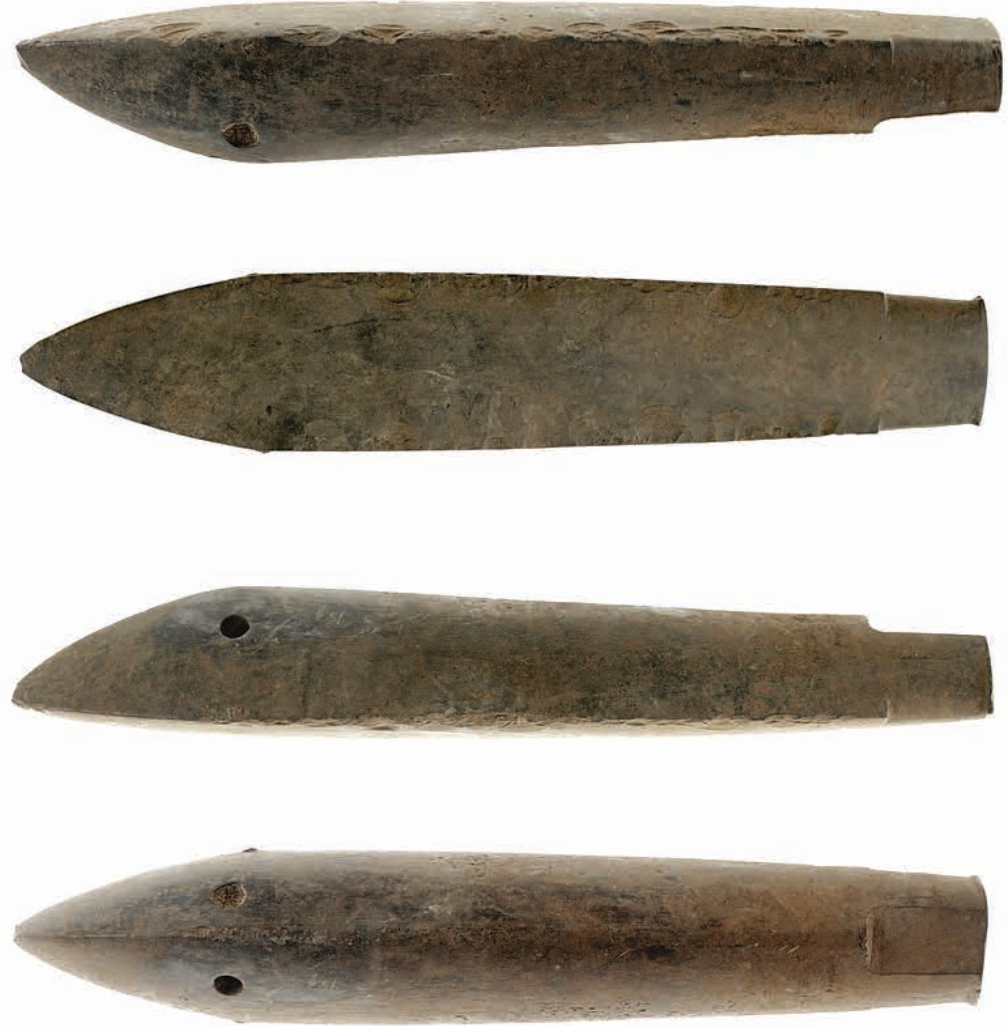

(a)

$100 \mathrm{~mm}$

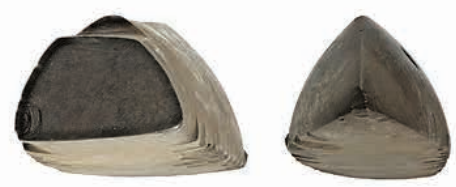

Figure 2 (a) Trolling lure shank from EA67, Waitapu, Ahuahu Great Mercury Island. (b) Terminology used to describe the trolling lure shank.

(c) $3 \mathrm{D}$ interactive model that can be activated when the PDF article is downloaded to your computer. 
(b)

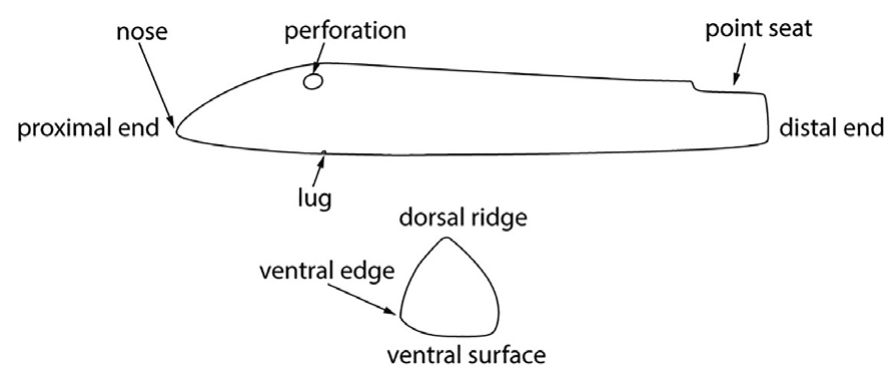

(c)

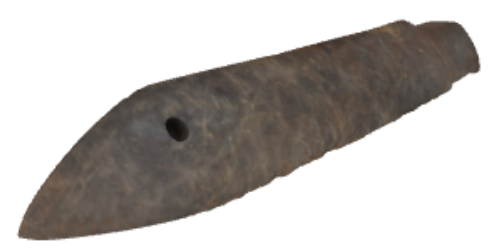

platform, and on the underside. These scars may relate to the manufacturing process to reduce the width and shape of the point platform but may also have been caused by point lashing. Forward of the point seat, on the right side, are short, deep parallel striations.

Although finely ground all over and finished with perforations and a point seat, a distinguishing feature is the number of shallow flake scars on the ventral edges from behind the perforations to near the point seat. The flake scars are mainly detached from the edges of the ventral surface and are shallow in the distal half on both sides, and deeper with more damage to the 
edges in the proximal half, but all are less than $1 \mathrm{~mm}$ depth. There is faint percussive bruising on the edges between the flake scars. Considerable skill in flaking stone would be required to detach shallow flakes without breaking the object (Dante Bonica, pers. comm., 2018). The flaking has not altered the cross-section shape and the lure does not appear to be in a damaged state which would necessitate repair. The ventral edges were examined under a microscope $(10 \times)$ to look for any features that might be erased by flaking. Notching on edges is common on some early artefact types including pendants, adzes and large lure shanks (Furey 2014; Prickett 1999), but there were none on this shank.

Polish adjacent to the point seat area suggests that there was lashing at one time in this area, probably for attaching a point. In contrast, the perforations do not have any apparent wear on the edges, as might be expected if there was regular stress and movement of the line lashing as the object moved through the water, or if the shank was suspended and worn as a pendant.

\section{Raw Material}

The shank is made from serpentinite and is mid to dark grey in colour, with veining, and mottles indicating deformed breccia. Prominent green veins near the distal end are possibly pumpellyite (Philippa Black, pers. comm., August 2017). Geochemical analysis was carried out using a Bruker Tracer III-SD portable X-ray fluorescence analyser (pXRF). For obsidian and basaltic stone specialised calibrations are used that have predictable ranges of chemical concentrations (Phillipps et al. 2016). However, because the chemical composition of the stone was unknown, a "general purpose" calibration, using 44 reference standards selected for a broad range of major and trace element concentration ranges, was used. ${ }^{1}$

A total of 21 elements were quantified as parts per million (ppm) and oxide weight percent (\%) concentrations (Table 2). For the majority of elements, the specimen was analysed in an air path through a filter composed of a 12 mil $(304.8 \mu \mathrm{m})$ layer of $\mathrm{Al}$ and a $1 \mathrm{mil}(25.4 \mu \mathrm{m})$ layer of Ti (Bruker's "yellow" filter), with an X-ray tube setting of $40 \mathrm{keV}$ at $28 \mu \mathrm{A}$. To increase sensitivity, the three lightest elements $\left(\mathrm{MgO}, \mathrm{Al}_{2} \mathrm{O}_{3}\right.$ and $\left.\mathrm{SiO}_{2}\right)$ were measured without a filter using an $\mathrm{X}$-ray tube setting of $15 \mathrm{keV}$ at $27 \mu \mathrm{A}$. The precision of non-destructive pXRF analyses for these light elements is lower than that of destructive WDXRF, so they are rounded to the closest whole oxide weight percent.

The stone was analysed four times on different portions of the surface to check for variation. Additionally, the darker green vein, large enough to cover the analysis area of the detector, was analysed separately. 
Table 2. Average chemical concentrations for the stone from analyses on four different parts of the surface, and from a darker vein, compared to two serpentinite samples from D'Urville Island (data from Sivell and Waterhouse 1986: Table 1).

\begin{tabular}{|c|c|c|c|c|c|c|}
\hline & \multirow[b]{2}{*}{ LOD* } & \multicolumn{2}{|c|}{ Typical surface } & \multirow[t]{2}{*}{ Darker vein } & \multicolumn{2}{|c|}{ D’Urville Is. } \\
\hline & & Mean & S.D. & & KP80 & KP92 \\
\hline $\mathrm{MgO}$ & $1.2 \%$ & 21 & 2.7 & 23 & 32.59 & 38.12 \\
\hline $\mathrm{Al}_{2} \mathrm{O}_{3}$ & $1.1 \%$ & 7 & 1.4 & 7 & 15.66 & 12.91 \\
\hline $\mathrm{SiO}_{2}$ & $3.5 \%$ & 34 & 3.7 & 36 & 36.12 & 39.19 \\
\hline $\mathrm{K}_{2} \mathrm{O}$ & $0.09 \%$ & $<\mathrm{LOD}$ & & $<$ LOD & 0.00 & 0.00 \\
\hline $\mathrm{CaO}$ & $0.09 \%$ & 0.61 & 0.024 & 0.27 & 0.51 & 0.33 \\
\hline $\mathrm{TiO}_{2}$ & $0.03 \%$ & 0.83 & 0.104 & 0.74 & 1.36 & 1.01 \\
\hline $\mathrm{MnO}$ & $0.02 \%$ & 0.40 & 0.002 & 0.38 & 0.77 & 0.57 \\
\hline $\mathrm{Fe}_{2} \mathrm{O}_{3}$ & $0.14 \%$ & 5.91 & 0.247 & 7.39 & 13.05 & 7.32 \\
\hline V & $22 \mathrm{ppm}$ & 107 & 10.9 & 133 & 355 & 232 \\
\hline $\mathrm{Cr}$ & $20 \mathrm{ppm}$ & 81 & 48.1 & 65 & 79 & 103 \\
\hline $\mathrm{Ni}$ & $5.5 \mathrm{ppm}$ & 67 & 5.4 & 30 & 100 & 114 \\
\hline $\mathrm{Cu}$ & $4.3 \mathrm{ppm}$ & $<$ LOD & & $<$ LOD & 36 & 18 \\
\hline $\mathrm{Zn}$ & $2.9 \mathrm{ppm}$ & 167 & 7.4 & 162 & 85 & 59 \\
\hline $\mathrm{Ga}$ & $2.0 \mathrm{ppm}$ & 6 & 0.9 & 7 & & \\
\hline $\mathrm{Pb}$ & $3.4 \mathrm{ppm}$ & $<\mathrm{LOD}$ & & $<\mathrm{LOD}$ & & \\
\hline Th & $2.5 \mathrm{ppm}$ & $<$ LOD & & $<$ LOD & & \\
\hline $\mathrm{Rb}$ & $2.3 \mathrm{ppm}$ & $<$ LOD & & $<$ LOD & 5 & 4 \\
\hline $\mathrm{Sr}$ & $3.8 \mathrm{ppm}$ & 9 & 1.1 & 7 & 4 & 2 \\
\hline Y & $1.3 \mathrm{ppm}$ & 21 & 0.9 & 21 & 13 & 8 \\
\hline $\mathrm{Zr}$ & $3.1 \mathrm{ppm}$ & 148 & 9.1 & 157 & 92 & 52 \\
\hline $\mathrm{Nb}$ & $1.2 \mathrm{ppm}$ & 6 & 2.7 & 4 & 1 & 1 \\
\hline $\mathrm{H}_{2} \mathrm{O}+$ & $\%$ & & & & 10.99 & 11.66 \\
\hline
\end{tabular}

${ }^{*}$ Limit of Detection (LOD). 
The relatively low concentrations of $\mathrm{SiO}_{2}(34 \%)$ and $\mathrm{K}_{2} \mathrm{O}(<0.09 \%)$ and high concentration of $\mathrm{MgO}(21 \%)$ suggest the stone is ultramafic, supporting the visual identification of serpentinite based on the specimen's green colour and veining. With the exception of $\mathrm{Fe}_{2} \mathrm{O}_{3}$, which is approximately $1.5 \%$ higher in value than the average surface concentrations, the composition of the darker green vein is similar to other portions of the artefact.

For unaltered volcanic rocks such as obsidians and basalts, particular deposits often have distinctive chemical compositions, and on this basis it is possible to identify their geographical origins with a good degree of confidence. Ultramafic rock sources, in contrast, can be difficult to characterise as the degree of serpentinisation can vary within deposits, and this can alter elemental compositions (Challis 1965: 335). In addition, comprehensive geochemical data for New Zealand serpentinites are currently lacking (Nick Mortimer, GNS, pers. comm., 2017).

There are limited locations where such material might be found. In the D'Urville Island-Nelson area they are geologically associated with metasomatised argillites used for making adzes. Sources are also present in Otago and South Westland, and from northern locations including Piopio in the King Country, North Cape and Pāremoremo near Auckland (Thompson et al. 1995). None of the North Island sources are known to have been accessed or used by Māori in pre-European times.

Large differences in trace element concentrations might, however, provide some clues to the geographical source. New Zealand serpentinites often have high concentrations of nickel $(\mathrm{Ni})$ and chromium $(\mathrm{Cr})$, ranging from approximately 1,000 to 5,000 ppm (Challis 1965; Sivell and Waterhouse 1986). In contrast, the shank has much lower concentrations of these elements, each below $100 \mathrm{ppm}$ (Table 2). Two serpentinite samples from D'Urville Island reported by Sivell and Waterhouse (1986: Table 1) also have anomalously low concentrations of these elements and broadly similar concentrations for most elements. Also notable is the large range of chemical variation in the two D'Urville Island samples. The similarity in results between the shank and the reported samples suggest D'Urville Island is a possible source of the serpentinite.

\section{ARCHAEOLOGICAL CONTEXT OF THE AHUAHU SHANK}

The Ahuahu shank was found at the southern end of excavations on T10/360 situated on a gently sloping ridge bordering Coralie Bay on the east side of the central tombolo of Ahuahu (Fig. 1). The ridge of weathered rhyolite is mantled by sand blown up from Coralie Bay. At the northern end of the ridge there were two distinct occupations that presented very different evidence. The upper occupation, dated to the eighteenth century, was confined to a small 
area and consisted of fire scoops and postholes. Underneath was an earlier occupation, more extensive in extent, and separated from the upper deposits by $60 \mathrm{~cm}$ of sterile sand. The earlier occupation at the northern end consisted of a large quantity of obsidian flakes and little else. Veins of charcoal running through the sand at the base of the excavation represent burnt roots of the original vegetation cover, and samples taken for dating will be discussed in the following section.

Continuous excavation up the ridge for over $23 \mathrm{~m}$ revealed that depth below surface of the earlier deposits (layers) reduced with distance up the ridge. The deposits contained stone artefacts including hammer stones, adzes, several pendants, moulded cylinders of kokowai 'ochre' and a large number of obsidian stone flakes, along with cetacean teeth, bones of dog (Canis familiaris) and sea mammal and a small quantity of moa bone. Teeth of white pointer shark (Carcharodon carcharias), several of which were perforated for use as ornaments, were present throughout the excavation area. Bone and shell material were scarce and preservation generally poor.

Volcanic boulders of varying size protruded from the underlying weathered rhyolite on the ridge. Some, including a large, relatively flat boulder near the southern margin of the excavation, were visible on the surface. The shank was found to the east of the boulder approximately $30 \mathrm{~cm}$ below the surface near the base of the occupation deposit (Fig. 3). Also nearby were a notched pendant made from petrified wood and a shaped imitation whale tooth pendant. Similar shaped pendants have been found in early settlement sites such as Houhora and Wairau Bar (Duff 1977; Furey 2002).

The stratigraphy was similar over the length of the ridge. A thin turf and recently developed topsoil overlay a thin black sand lens that was interpreted as a washed surface where organic material concentrated. Below this were thin lenses of wind-laid sand over an occupation deposit defined by the presence of stone flakes. The overlying deposits were devoid of in situ flakes and the occupation deposit was easily distinguished from later sand build-up. The shank was found near the interface of the occupation deposit (ID 42510) and natural sand ${ }^{2}$ (Fig. 4). A fire feature (ID 42509) containing numerous firecracked rocks, charcoal and fragmented decomposed bone of bird, fish and sea mammal was $1.2 \mathrm{~m}$ from the lure and contemporary with the occupation deposit. Dateable charcoal samples were obtained. The occupation contained no evidence of cooking, food waste discard other than what was in the fire feature, or postholes. There were also no features other than a shallow depression containing charcoal and artefacts at the northern end of the ridge and the fire feature at the southern end. This absence, contrasting with the presence of so much worked stone, makes the occupation evidence unusual and difficult to interpret. 
102 A Large Trolling Lure Shank from Ahuahu Great Mercury Island

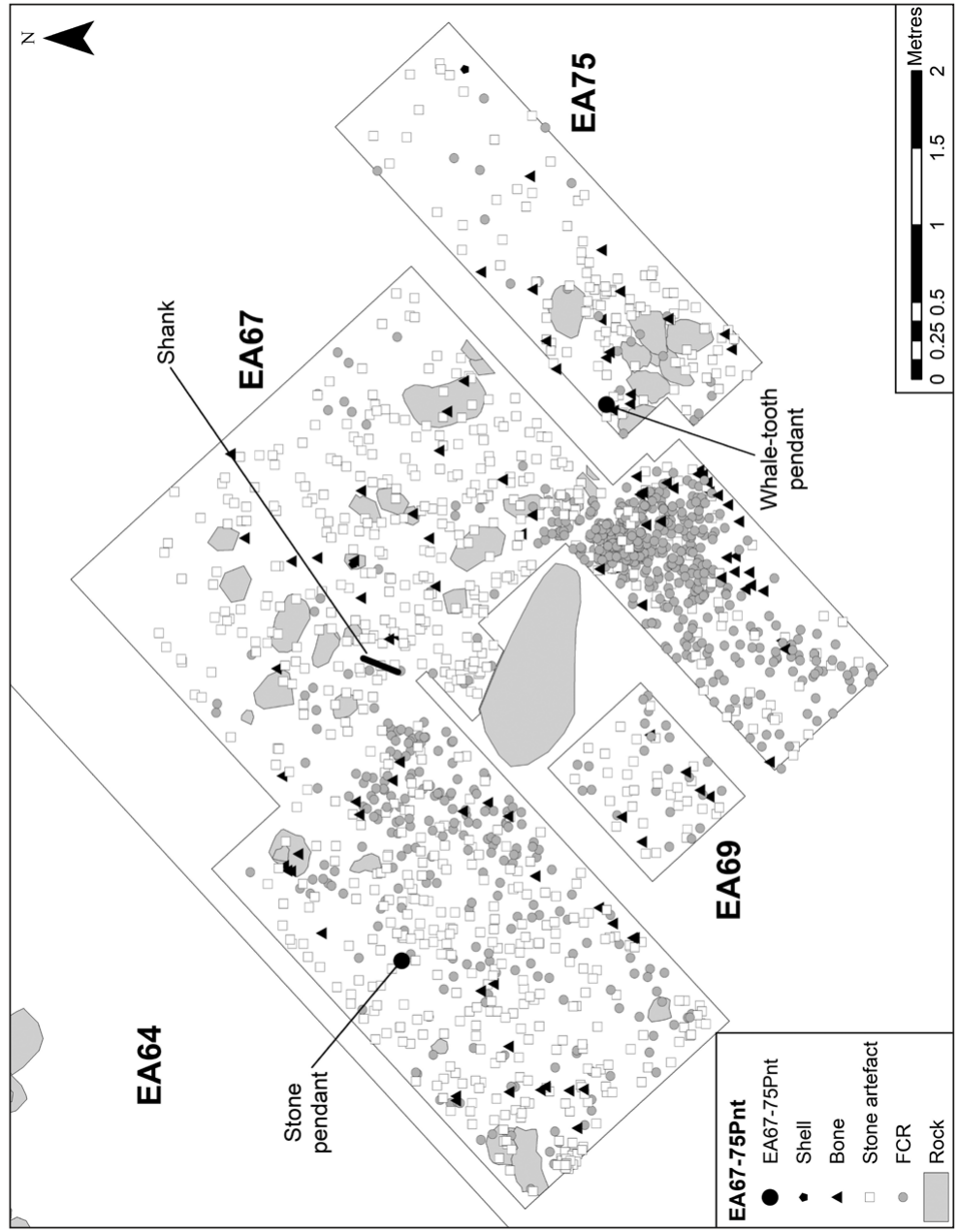

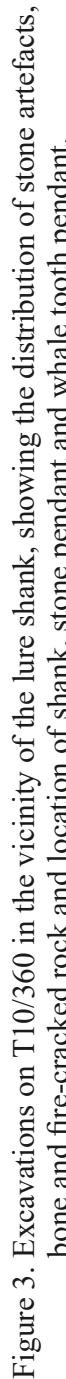




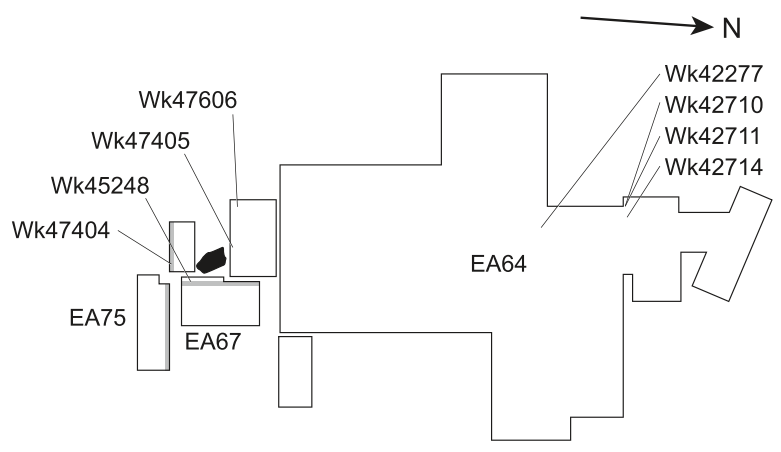

EA67 West profile

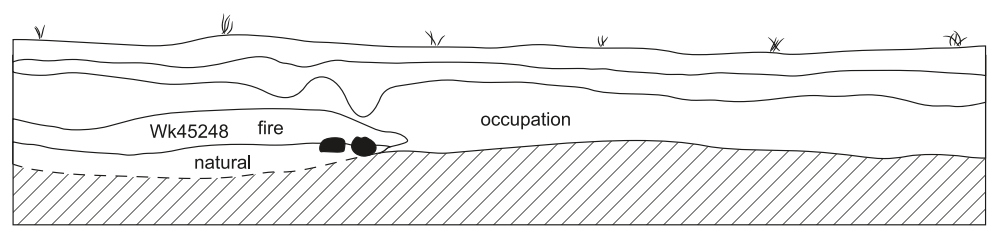

EA75 North profile
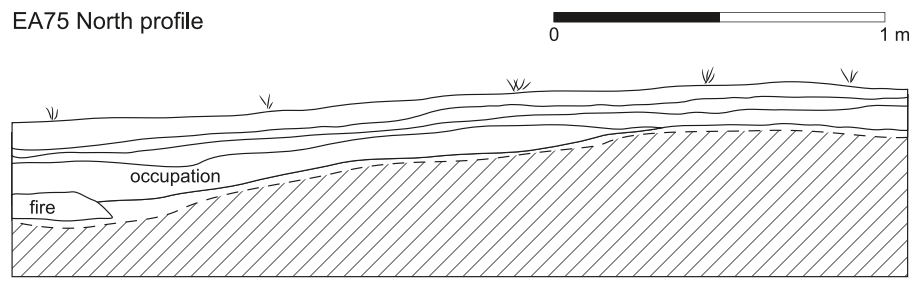

EA67 South profile
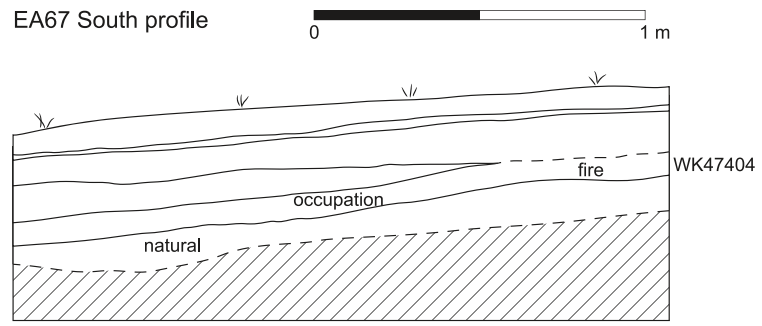

Figure 4. Stratigraphy in the vicinity of the find showing where radiocarbon samples were obtained, and depth of the artefacts referred to in the text. 
DATING

Radiocarbon determinations Wk47404 and Wk45248 on short-lived species from the fire feature are in close agreement and indicate use in the early 1400s CE (Table 3; Fig. 5). Wk47406, twig charcoal tānekaha (Phyllocladus trichomanoides), was obtained from a lens of charcoal near the base of deposit 42510. While the sample was stratigraphically within the occupation deposit, the result aligns more closely with dates from the northern end of the ridge interpreted as burning of the primary vegetation. A second sample (Wk47405) from the surface of the same deposit consisted of short-lived species: tutu

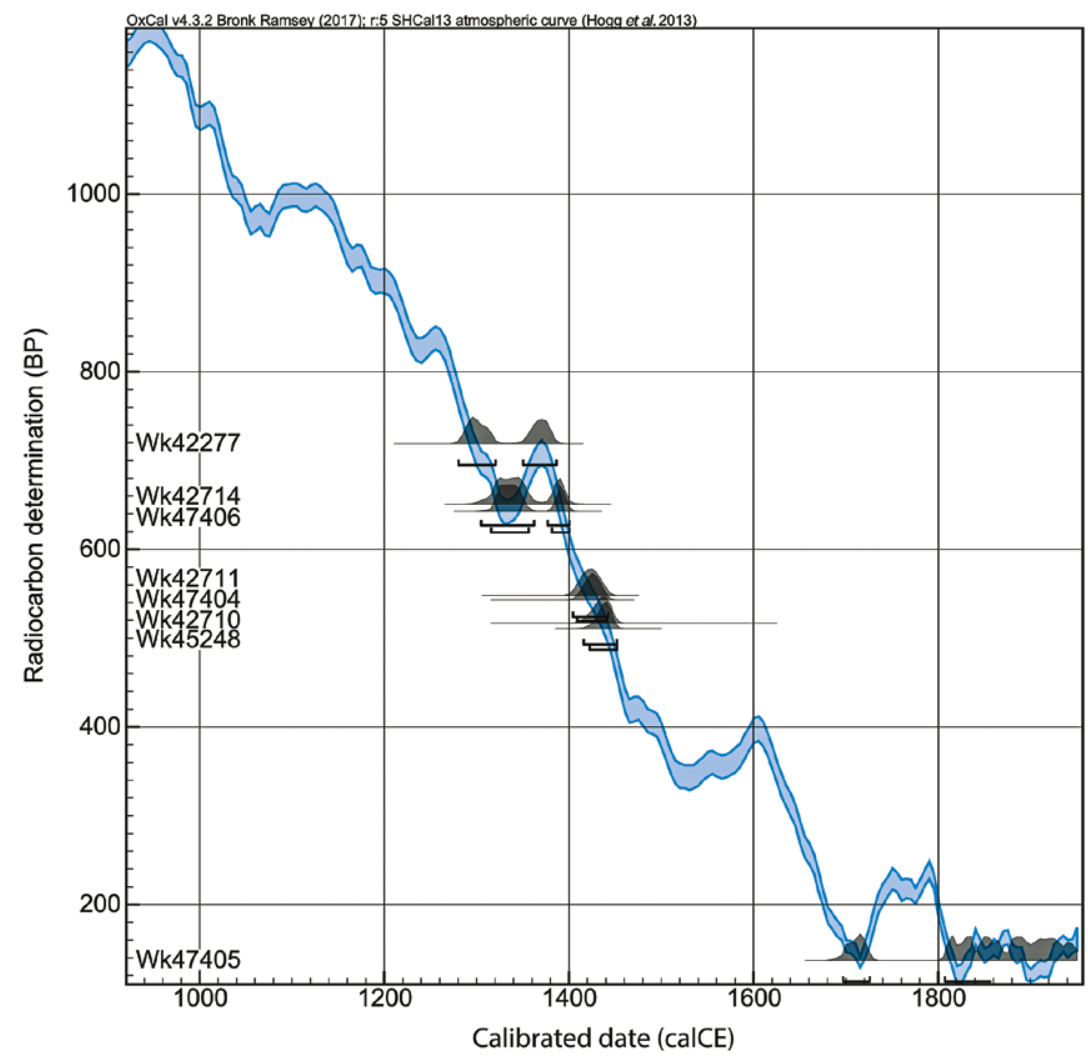

Figure 5. Plotted radiocarbon determinations from Table 3. Calibration completed and plot made in OxCal v4.3.2 (Bronk Ramsey 2009, 2017), using SHCal13 atmospheric curve (Hogg et al. 2013). 
Louise Furey et al. 105

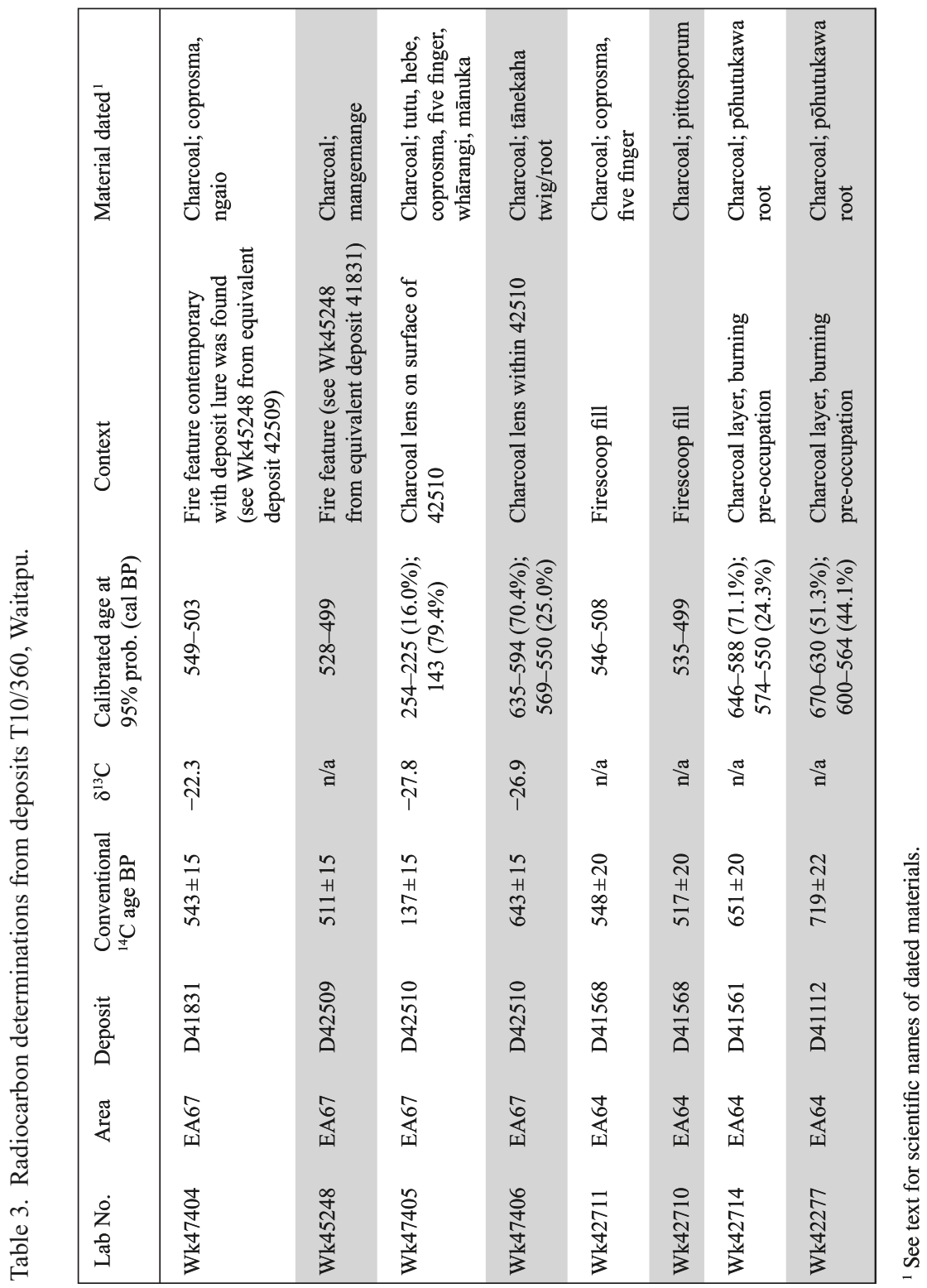


(Coriaria sp.), coprosma (Coprosma sp.), whārangi (Melicope ternata), mānuka (Leptospermum scoparium), five finger (Pseudopanax arboreus) and hebe (Veronica sp.). The sample did, however, return a more recent age estimate and is interpreted as vegetation growing on the site post-occupation.

Underneath the cultural deposit in EA64 at the northern end of the ridge were several burnt pōhutukawa (Metrosideros excelsa) root balls that were followed outwards to extract small-diameter root charcoal. Two dates (Wk42714, Wk42277) from separate trees give results similar to Wk47406 in deposit 42510 near the shank. Due to fluctuations in the atmospheric curve there are two possible age ranges, although there is a higher probability for the earlier peak, suggesting Māori burnt the primary forest in this area several decades prior to the ridge being lived on and cultural material deposited.

While it has long been accepted that the triangular trolling lure shanks of this form are associated with the early period of Māori settlement, prior to finding the Ahuahu shank none had been recovered in situ and deposition could not therefore be directly dated. The date for the deposit in which the Ahuahu shank was found (CE 1431-1447 at 68.2\% confidence, or CE 14221456 at $95.4 \%$ ) is slightly later than most dates from Shag River Mouth that cluster in the fourteenth century (Anderson et al. 1996). However, some Shag River Mouth determinations fall outside that range and are comparable to the Ahuahu dates. As the shanks from Shag River lack archaeological context, they cannot indisputably be attributed to the part of the site that was excavated. The radiocarbon determinations from Wairau Bar are from different contexts and multiple materials, and a broad age range of mid-thirteenth century to fourteenth century (Higham et al. 1999: 425; Jacomb et al. 2014), but again the dating does not relate directly to the shanks that were ploughed or dug up with little or no control. However, the large assemblage of artefacts from Wairau Bar is clearly from the initial settlement period. An age determination from Panau, obtained from a lower part of the site, suggests mid to late fourteenth century (Jacomb 2000: 107), but again artefacts including the shank were from fossicked contexts, and stylistically most are from several centuries later. Locations of other finds are undated.

\section{DISCUSSION}

The identification of large trolling lure shanks as an artefact category associated with early occupation of Aotearoa is largely attributed to the activities of collectors rather than archaeological excavation. This makes the well-provenienced Ahuahu shank particularly remarkable. It was found on its ventral surface with other items rarely found in archaeological sites, including unmodified teeth of sperm whale and elephant seal, a notched pendant, perforated white pointer shark teeth, an imitation whale tooth pendant and shaped cylinders of kokowai in addition to the more usually 
found adzes, hammer stones and flaked stone. This combination of finds is unusual in sites of similar age on the Coromandel east coast where fish hooks of moa bone, adze roughouts and finished adzes are common (Davidson 1979), together with artefacts in the process of being made and the manufacturing tools.

The Ahuahu shank was found in deposits dating to the early to mid1400s CE. However, this was the time it entered the archaeological record, not when it was manufactured. The rarity of large shanks suggests that, once made, objects of this form were likely carefully looked after, but the history of the lure prior to deposition on Ahuahu is unknown. Use polish adjacent to the point seat area suggests wear from fibre lashing, presumably associated with hook attachment, but the combination of shank and hook does not necessarily indicate that it functioned as a working lure for catching fish. The perforations do not have any wear on the edges as might be expected if there was regular stress and movement of the line lashing as the object moved through the water. Similarly, if the shank was a pendant, as suggested for similar large examples (Anderson 1981), wear would be expected around the perforation - especially as, from observation of reels and other pendant forms, serpentinite can display heavy wear in this area.

There is no direct indication from the archaeological context in which the Ahuahu lure shank was found that might suggest why it was there. The lure is not part of a human burial, nor are such remains indicated in excavated areas of the site. As noted, other rare artefact forms are present, and within the same set of deposits there are numerous stone artefacts, so the shank is not an isolated find. There is no obvious indication it was discarded because it required repair-it appears to be a finished, unbroken object. The most unusual feature is that it was modified by detachment of fine flakes from the ventral surface after grinding was complete. These flakes do not appear to have removed any features such as notching and the flaking is not sufficiently invasive to have altered the profile. The flaking is in sharp contrast to its otherwise ground and polished appearance, and it is highly likely the flaking was not part of the manufacturing process but occurred at some later time in its life history.

The shank was made from stone almost certainly from a South Island source. We are not aware of unmodified blocks of serpentinite having been found in northern archaeological sites, and there are no fragments of the stone in this or any other excavated site on the Coromandel Peninsula. Indeed serpentinite artefacts in the region are very rare, with only four reels and one small trolling lure shank known. The shank is therefore likely to have been made close to the stone source and transported in its finished state. It may have passed through a number of social interactions before finally being deposited on Ahuahu in circumstances unknown. 
Serpentinite artefacts of any form are not common, although occurrence of the material is higher in South Island sites and use of the material is confined to sites pre-1500 CE.

The large size of the shank suggests it did not function as a lure to catch fish. With a seat platform measuring $26 \times 15 \mathrm{~mm}$, the point would also have been large. Museum and excavated assemblages have no examples of the substantial point required, and trolling lure points (or any other type of fish hook) have not been found in the Waitapu excavations.

If the object did not function as a fish hook, then what was it used for? Archaeology cannot address the question without an awareness of the cultural setting in which it was used, or how an object of this type might have been perceived. It is, however, too restricting and convenient an interpretation to see it solely as a trolling shank, or as a pendant. Large so-called shanks may have been fashioned to resemble functional trolling shanks and acted as such in a symbolic rather than a literal way. Hamilton (1908) hints at this by using the term whatu for large hooks and Best (1929: 3-4) uses the same term for a mauri, or object the gods inhabit, in relation to fishing. The large shank from Kaipara (AM1456, acquired 1928) is described in the Auckland Museum Ethnology Register as a "manea or kanawhi, a ceremonial fishing charm in the form of a trolling lure shank", thereby drawing a distinction between a functional fish hook shank and an item used in ritual.

The objects the shank was found with were not everyday items, and whale tooth and shark tooth ornaments are suggestive of culturally relevant messages related through material and form (Neich and Pereira 2004). Large shanks may have had multiple meanings according to the context and may have been an important conduit in communicating and displaying the presence of godly embodiments, as discussed by Clunie (2013) for Tongan tapua 'ceremonial gift whale teeth' and trolling shanks. In another example, from Tokelau (Huntsman 2017), a wedding is marked by the gifting of a fishing lure $(p \bar{a})$ manufactured from a specially selected pearl-shell with markings that resemble those on skipjack tuna (Katsuwonus pelamis). The gifting is formalised by the placement of the lure around the bride's neck. In this particular context, and for a short time, the suspended lure is called a $k a h o a$ or pendant. Later the pendant is rebound as a $p \bar{a}$ and used for fishing. Gifting the specially made lure not only acknowledges relationships between families but also future success in fishing to provide for the well-being of both families. In addition, the material, and its resemblance to the patterning on the sought-after fish, evokes cosmological meanings within Tokelauan society. The object therefore has meaning according to context, with the objective of productivity from the marriage and successful fishing. As an archaeological find, an item symbolically presented in this way would be indistinguishable from other $p \bar{a}$ made solely for fishing. 
The Ahuahu lure is not an ordinary lure indistinguishable from others, and the rarity of large items are likely to have overtones of mana 'prestige' and a symbolic function, especially when made of a rarely used material. The resemblance to functional trolling lure shanks indicates that the Ahuahu shank, and other large examples, had a specialised role in relation to catching fish. While ethnographic accounts relate the role of such objects in fishing and social transactions, there are no parallels to explain how the shank came to be modified by flaking, and its subsequent incorporation in the archaeological record.

\section{***}

A serpentinite trolling lure shank excavated from Waitapu, Ahuahu, is the largest yet recorded in Aotearoa. There is no evidence of damage or fracture that might explain its abandonment. Radiocarbon determinations indicate deposition at some time in the first half of the fifteenth century. The lure shank is associated within the broad archaeological context with rarely found objects, and there were no features such as postholes, cooking or food-related discard that are typical components of sites of similar age on the Coromandel Peninsula. There is no direct evidence that the lure shank ever functioned to catch fish, and while an alternative interpretation that it acted as a pendant has been considered, there is equally no evidence that it was hung from a cord. The find has significance not only for extending understanding Māori material culture in the first few hundred years of settlement but also for being able to address ritual in an archaeological setting.

\section{ACKNOWLEDGEMENTS}

Thanks to Rachel Wesley and Moira White, Otago Museum; Hatesa Seumanutafa and Roger Fyfe, Canterbury Museum; David Duffield, Southland Museum; Dougal Austin, Te Papa; and Graeme Collett, Phillip Latham and Brian Allingham, Dunedin, for information on collections. Thanks also to Professor Philippa Black for stone identification and Hugh Grenfell, Auckland Museum, for geological information. Tim Mackrell imaged the object (Fig. 2), Seline McNamee and Matthew Campbell assisted with figures and Dante Bonica provided specialist knowledge about stone working. Two anonymous referees provided feedback that improved the manuscript. The authors acknowledge the continuing support received from Sir Michael Fay and Ngāti Hei.

\section{NOTES}

1. The full report on the XRF analysis of the lure can be obtained from Andrew McAlister.

2. Each layer or deposit excavated was assigned a unique identifier in the Ahuahu Project database. As there were several excavations over four years, the 
archaeologically continuous deposits were given separate numbers during each excavation and linked together in the geographic information system (GIS). For this part of the excavation, the occupation deposit in the vicinity of the lure and large stone has been assigned 41888, 42510, 41972 and 42028 depending on the excavation area, and the fire feature 41831, 42509 and 41971. The excavation areas (EA) relevant to this discussion are EA64 on the northern end of the ridge and EA67 and EA75 at the southern end.

\section{REFERENCES}

Allingham, B., 1983. Preliminary notes on a coastal moa-hunter site at Warrington, Otago. New Zealand Archaeological Association Newsletter 26 (4): 228-30.

Anderson, A., 1981. A lure hook shank from Shag River Mouth, Otago. New Zealand Archaeological Association Newsletter 24 (4): 280-82.

Anderson, A. and W. Gumbley, 1996. Fishing gear. In A. Anderson, B. Allingham and I. Smith (eds), Shag River Mouth: The Archaeology of an Early Southern Maori Village. Canberra: ANH Publications, pp. 148-60.

Anderson, A., I. Smith and T. Higham, 1996. Radiocarbon chronology. In A. Anderson, B. Allingham and I. Smith (eds), Shag River Mouth: The Archaeology of an Early Southern Maori Village. Canberra: ANH Publications, pp. 60-69.

Ash, E.K., 2017. A formational approach to the analysis of Polynesian dog remains from Ahuahu (Great Mercury Island), New Zealand. MA thesis, Anthropology, School of Social Sciences, University of Auckland.

Best, E., 1929. Fishing Methods and Devices of the Maori. Wellington: Government Printer.

Bronk Ramsey, C., 2009. Bayesian analysis of radiocarbon dates. Radiocarbon 51 (1): 337-60. DOI: 10.1017/S0033822200033865

2017. OxCal Program (version 4.3). Oxford: Radiocarbon Accelerator Unit, University of Oxford.

Challis, G.A., 1965. The origin of New Zealand ultramafic intrusions. Journal of Petrology 6 (2): 322-64.

Clunie, F., 2013. Tapua: "Polished ivory shrines" of Tongan gods. Journal of the Polynesian Society 122 (2): 161-224.

Davidson, J.M., 1979. Archaic middens of the Coromandel region: A review. In A. Anderson (ed.), Birds of a Feather: Osteological and Archaeological Papers from the South Pacific in Honour of R.J. Scarlett. NZ Archaeological Association Monograph II, BAR International Series 62. Oxford: BAR, pp. 183-202.

Duff, R., 1977. The Moa-Hunter Period of Maori Culture. Wellington: Government Printer.

Findlater, A., 2011. Recontextualising Material Culture: An Investigation of the Minnow Lure Shanks from Kawatiri River Mouth and Wairau Bar, Southern New Zealand. MA thesis, University of Otago, Dunedin.

Furey, L., 1990. The artefact collection from Whitipirorua (T12/16), Coromandel Peninsula. Records of Auckland Institute and Museum 27: 19-60. 
Furey, L., 2002. Houhora: A Fourteenth Century Maori Village in Northland. Bulletin of the Auckland Museum No. 19. Auckland: Auckland War Memorial Museum. 2014. Adzes with notches. Records of Auckland Museum 49: 5-13.

Furey, L., J. Emmitt, R. Phillipps, T. Ladefoged, A. Jorgensen and S. Holdaway, 2017. Brief interim report for excavations on Ahuahu Great Mercury Island, June 2014-February 2017. Archaeology in New Zealand 60 (3): 45-63.

Golson, J., 1958. Notes and queries: [598] A stone minnow shank from Northland. Journal of the Polynesian Society 67 (1): 74-77.

Hamilton, A., 1908. Fishing and sea-foods of the Ancient Maori. Dominion Museum Bulletin No. 2. Wellington: Government Printer.

Higham, T., A. Anderson and C. Jacomb, 1999. Dating the first New Zealanders: The chronology of Wairau Bar. Antiquity 73 (280): 420-27.

Hogg, A., Q. Hua, P. Blackwell, M. Niu, C. Buck, T. Guilderson, T.J. Heaton, et al., 2013. SHCal13 Southern Hemisphere calibration, 0-50,000 years cal BP. Radiocarbon 55 (4): 1889-1903. DOI: 10.2458/azu_js_rc.55.16783

Huntsman, J., 2017. The treasured things of Tokelau. Journal of the Polynesian Society 126 (3): 253-82.

Jacomb, C., 2000. Panau: The Archaeology of a Banks Peninsula Maori Village. Canterbury Museum Bulletin 9. Christchurch: Canterbury Museum.

Jacomb, C., R. Holdaway, M. Allentoft, M. Bunce, C. Oskam, R. Walter and E. Brooks, 2014. High-precision dating and ancient DNA profiling of moa (Aves: Dinornithiformes) eggshell documents a complex feature at Wairau Bar and refines the chronology of New Zealand settlement by Polynesians. Journal of Archaeological Science 50: 24-30.

Neich, R. and F. Pereira, 2004. Pacific Jewellery and Adornment. Auckland: David Bateman and Auckland Museum.

Phillipps, R.S., A.J. McAlister and M.S. Allen, 2016. Occupation duration and mobility in New Zealand prehistory: Insights from geochemical and technological analyses of an early Māori stone artefact assemblage. Journal of Anthropological Archaeology 42: 105-21.

Prickett, N., 1999. Nga Tohu Tawhito: Early Maori Ornaments. Auckland: David Bateman.

Sivell, W.J. and J.B. Waterhouse, 1986. The geochemistry, origin, and tectonic significance of rodingites from the Dun Mountain ultramafics, D'Urville Island, New Zealand. New Zealand Journal of Geology and Geophysics 29 (1): 9-27.

Skinner, H.D., 1942. A classification of the fish-hooks of Murihiku. Journal of the Polynesian Society 51 (4): 256-86.

Teviotdale, D., 1929. Notes on stone and moa-bone fish-hook shanks in the Otago University Museum. Journal of the Polynesian Society 38 (4): 270-80.

Thompson, B., B. Brathwaite and T. Christie, 1995. Mineral wealth of New Zealand. Institute of Geological \& Nuclear Sciences Information Series 33. Lower Hutt: Institute of Geological \& Nuclear Sciences. 


\section{AUTHOR CONTACT DETAILS}

Corresponding author: Louise Furey, Auckland War Memorial Museum, Private Bag 92018, Victoria Street West, Auckland 1142, New Zealand. Email: 1furey@aucklandmuseum.com

Rebecca Phillipps, Anthropology, School of Social Sciences, University of Auckland, Private Bag 92019, Auckland 1142, New Zealand. Email: r.phillipps@auckland.ac.nz

Joshua Emmitt, address as above. Email: josh.emmitt@auckland.ac.nz

Andrew McAlister, address as above. Email: andrew.mcalister@auckland.ac.nz

Simon Holdaway, address as above. Email: sj.holdaway@auckland.ac.nz 


\section{REVIEWS}

COCHRANE, Ethan E. and Terry L. Hunt (eds): The Oxford Handbook of Prehistoric Oceania. Oxford: Oxford University Press, 2018. 513 pp., biblio., illus., index. US\$150.00 (cloth).

\section{BENJAMIN DAVIES \\ University of Utah}

The Oxford Handbook of Prehistoric Oceania, edited by Ethan Cochrane and Terry Hunt, joins the ranks of the Oxford Handbook series that aims to provide "up-to-date surveys of original research in a particular subject area". While sole author surveys benefit from the consistency of their underlying narrative, edited volumes often present a wider range of viewpoints and highlight issues currently under debate. Comprised of 21 chapters written by leading researchers, the handbook is a trove of information organised principally along a regional-temporal framework that will be familiar to anyone studying the deep past of the Pacific.

The first few chapters deal with the arrival of humans and subsequent cultural Near Oceania, and exemplify the strengths of the multi-author survey. O'Connor and Hiscock summarise Pleistocene migrations of humans into greater Australia and Near Oceania from mainland Asia, addressing contested topics like migration routes and megafaunal extinction. Denham presents evidence from island Southeast Asia and challenges the prevailing notion that Austronesian languages dispersed through this region and into wider Oceania as part of a coherent cultural and genetic package carried by voyager-farmers from Taiwan. Complementary chapters on New Guinea and its adjacent islands (by White and Specht, respectively) likewise discuss ongoing debates, particularly related to subsistence practices and interaction, but also address uncertainties from limited investigative coverage.

Heading into Remote Oceania, the book features several chapters on island groups defined by their contemporary political boundaries, an approach that works well since each group has a unique history of archaeological research. This is particularly striking in the chapter from Sand, who reviews the archaeology of New Caledonia against the backdrop of colonialism and Kanak cultural ownership, raising questions of archaeology's value to indigenous people. Along similar lines, Bedford and Spriggs conclude their summary of Vanuatu archaeology by highlighting the growing role of the Vanuatu Cultural Centre in directing archaeological research and coordinating public outreach.

The prominence of movement and interaction is an expected element of a text on the Pacific past, and this becomes increasingly apparent as the text moves further out into Remote Oceania. Mobility is considered key to understanding cultural change in Fiji, where Cochrane uses evidence from a wide range of sources (archaeological, biological, linguistic) to show changing scales of interaction over time, and in Tonga and Sāmoa, where Burley and Addison argue for differences in connectivity and exchange between the two archipelagos driving social differences in both ceramic 
and aceramic periods. Chapters on western and eastern Micronesia emphasise the importance of voyaging and interaction as a stimulus for social complexity: Fitzpatrick pays particular attention to western exchange networks like the ethnographically known sawei, while Athens draws on Petersen's (2006) notion of a subsistence revolution facilitated by hybridisation of eastern and western breadfruit varieties.

Adaptation is also a recurrent theme throughout the text, especially in later chapters dealing with East Polynesia. East Polynesia encompasses substantial environmental variability between islands and island groups, requiring different adaptations from incoming human groups and influencing social organisation. Kahn illustrates this by comparing the cultural trajectories of Central East Polynesian archipelagos, particularly the Austral, Society and Marquesas groups, and Kirch describes how contrasts between dry and humid areas influenced the rise of socioeconomic inequality in an overview of the cultural history of Hawai' $i$. In a chapter on South Polynesia, Anderson avoids the problematic dichotomy between Archaic and Classic phases for Aotearoa/New Zealand with the inclusion of a "Middle Phase" defined by diverging adaptations between the highly productive north and the more ecologically sensitive south. Hunt and Lipo give a thorough review of the history of archaeological research and interpretation on Rapa Nui, where narratives of "ecocide" through deforestation and warfare have shifted toward recognition of long-term agricultural intensification and post-contact depopulation.

Several chapters discuss overarching ideas that do not fit neatly within the regional framework but are thematically important in the context of the Oceanic deep past. Some present these topics in a straightforward manner: Rieth and Cochrane, for example, provide a stock-taking of chronology in Remote Oceania, including a detailed consideration of changing approaches to dating in Hawai ' $i$, and a very useful two-and-a-half-page table listing the earliest dates from different island groups and their contexts, and corroborating archaeological and palaeoenvironmental data. Other chapters in this vein include Dickinson's succinct treatment of coastal geomorphology and its implications for human settlement, and Pawley's summary of linguistic research that underlies many models of origins, migration and subsequent interactions in Pacific.

There are also chapters that cover a topic while criticising prevailing thinking or practice. Denham's chapter on island Southeast Asia and Cochrane's essay on Fiji are examples of this, as is Morrison and O'Connor's review of settlement pattern studies in the Pacific. A predominant approach since the 1970s, the authors highlight settlement pattern research in Sāmoa and Hawai'i before raising questions about comparability between regions. Drawing on ideas from distributional archaeology and time perspectivism (see chapters in Holdaway and Wandsnider 2008), the authors set a series of practical goals to extend the range of future settlement pattern studies. Terrell's chapter on Lapita also falls into the critical category, invoking "baseline probability analysis" as a way to build more specificity into existing models and drawing on the pedagogical notion of "communities of practice" (Wenger 1998) as a way to bridge between localised behaviour and wider material distributions. This chapter is a thought-provoking contribution to be sure, but given its emphasis on epistemology and limited engagement with the wealth of existing work on Lapita, it is somewhat out of step with the rest of the book. 
In the final chapter, Anderson returns for a discussion of Pacific seafaring, commenting on "traditionalist" models that promote voyaging against the prevailing easterly winds of the Pacific. Although many experiments have demonstrated the efficacy of windward sailing for exploration, Anderson points out limitations in the available data on vessel performance characteristics, in particular on the antiquity of triangular, stayed-mast rigs. An alternative, "historicist" model bypasses the need for these by restricting travel to downwind, but also has serious ramifications for many of the ideas related to migration and interaction that occur throughout this book. This continues to be an active area of debate and research, thanks in no small part to Anderson's continued questioning of widely accepted narratives.

The sheer volume and diversity of subjects covered in this book is impressive, but at the same time this makes a few omissions easier to spot. The Solomon Islands, for example, receive little attention, which is curious given how thoroughly other island groups are covered. Also, given the substantial contributions of genetics in the last two decades, it is surprising that this received only passing mention in some chapters.

These issues aside, as a survey of contemporary research, the Oxford Handbook of Prehistoric Oceania succeeds and then some. Most chapters are very accessible as introductions to their respective topics, making the text useful for students and teachers. The wealth of information and the variety of views it contains makes this book a worthwhile investment for anyone interested in the deep history of the Pacific.

\section{References Cited}

Holdaway, Simon J. and LuAnn Wandsnider, 2008. Time in Archaeology: Time Perspectivism Revisited. Salt Lake City: University of Utah Press.

Petersen, Glenn, 2006. Micronesia's Breadfruit Revolution and the Evolution of a Culture Area. Archaeology in Oceania 41 (2): 82-92.

Wenger, Etienne, 1998. Communities of Practice: Learning, Meaning, and Identity. Cambridge: Cambridge University Press.

COOPER, Annabel: Filming the Colonial Past: The New Zealand Wars on Screen. Dunedin: Otago University Press, 2018. 304 pp., biblio., illus., index, notes. NZ\$49.95 (softcover).

\section{AMBER RHODES \\ University of Auckland}

Filming the Colonial Past: The New Zealand Wars on Screen looks at the way New Zealand productions have portrayed the colonial conflicts sometimes known as the New Zealand Wars. The wars took place in various regions across New Zealand between 1843 and 1916, causing major divisions between Māori and Pākehā 'New Zealand European' as well as between iwi 'tribal' groups. The title itself, Filming the Colonial Past, implies that the construction of our past occurred through the act of filming the interpretation of the past and, like the interaction between Māori and Pākehā in society, this past has been built through sometimes mutual and not always easy or equal means. The author has worked chronologically discussing the social 
and political context of the time in which each production was made. The interactions between Pākehā filmmakers and Māori actors, iwi representatives and later cultural advisors and people in senior roles is examined.

The initial sources of the history of the wars are discussed, mainly histories written by Pākehā men such as Elsdon Best and James Cowan. Cowan was fluent in te reo Māori 'Māori language' and was the only historian who interviewed veterans on both sides of the wars. Cooper considers the many constraints at play when making films: funding, casting, cultural misunderstandings, locations, partnerships between Māori and non-Māori over time and their respective expectations, practical restrictions and developments in technology, and surrounding social and political impacts. The author looks at each example and uncovers and explains the problems and solutions unique to that particular production, demonstrating along the way the development of how our histories have been constructed, and also how the relationships and expectations between Māori and non-Māori have evolved to where we are today: on the cusp of stronger Māori autonomy in filmmaking.

Creating the colonial past through film can be seen as a process of defining New Zealand's past, particularly during the early twentieth century when there was a search for a New Zealand identity and a desire to build "nationhood". The early films of Rudall Hayward were concerned with this idea of nationhood; in light of the recent experiences of New Zealanders, both Māori and Pākehā, in World War I, Hayward's films contributed to the formulating of national identity through his construction of a shared history and its heroes. The process of his filmmaking included approaching Princess Te Puea Hērangi to make the film in conjunction with Türangawaewae Marae and the Waikato people; although initially positive, this negotiation broke down and cast were used from Rotorua, where the film was finally shot. This breakdown seems to have stemmed from Hayward's impatience to get the film made and a lack of funding required to make the necessary financial contributions to the Princess. The issue of funding is a recurring one when it comes to telling our histories without restriction, with some exceptions.

Examining more recent representations of the colonial wars, the author points out that filmmakers from the 1970s onwards were aware that there was an "erosion of the collective memory of the New Zealand Wars through the middle of the twentieth century" (p. 24). The time was ripe to create memory and understanding of our histories in the national consciousness. Filmmaking in the 1970s coincided with the movement of decolonisation and political action taking place across Aotearoa. This "reforging of national identity" took place as social and political upheavals were dismantling historical ties to Britain. Two watershed moments in our screen history were born alongside these upheavals: the well-funded TVNZ series The Governor (1977) and Geoff Murphy's feature film Utu (1983). Both were wholly New Zealand-funded and both challenged long-held biased views of our histories.

In The Governor, iwi perspectives were introduced rather than solely relying on historians' views. Generally held positive views on Governor Grey were challenged; he was a far more complicated character than history had previously painted him to be. The Governor lent force to "contemporary Māori claims about land rights and historical injustice" (p. 123). This series could be considered a touchstone for 
reactivating mana 'prestige, spiritual power' for Māori involved in the film: "his people had sort of disappeared ... this is what I've [heard]... I'm giving you this secondhand ... they sort of disappeared, and with the programme they found their heritage which had been lost and forgotten, and it gave them their mana back" (p. 109). The issue of funding is a major one when it comes to telling our stories well. The balancing act required to maintain integrity and truth and the necessity to keep within budgets, make profits and do well at the box office is probably the reason it has been so long since we have had anything as good as The Governor.

The process of filmmaking is collaborative by necessity; it requires each group to invest and trust in the other, much like a good functioning bicultural society. In this way films have often been sites of unity. Cooper also critically assesses less successful attempts at telling our colonial history, such as Pictures and Greenstone. The former, produced in 1981, was based on the photographer Alfred Burton but never moved "beyond clichéd interactions between Māori and Pākehā, and there seems to have been little Māori involvement in the film" (p. 127). This was soon overshadowed by the nuanced and vital film Utu. Greenstone from 1999 seems to have suffered from the influence of its BBC funders and tensions between the writers, and appeared to have missed the mark; writer Greg McGee's view was that the production became "a sort of bastard child of the imperialists[;] it perfectly replicated what it was conveying [colonial exploitation]" (p. 188).

Cooper does an excellent job of weaving together the various strands of filmmaking: writing, shooting, political and social influences and pressures, the interactions of Māori and Pākehā, cast, crew and kaitiaki 'caretakers', funding issues and cultural misunderstandings (from Rudall Hayward to Samantha Morton). It is a comprehensive book, balanced in its overview and its understanding of how the construction of the colonial past has evolved and developed according to contemporary understandings, primary and secondary sources, historical documents and oral traditions and memories. 


\section{PUBLICATIONS RECEIVED*}

September 2019 to March 2020

BERMAN, Elise: Talking Like Children: Language and the Production of Age in the Marshall Islands. New York: Oxford University Press, 2019. 224 pp., biblio., illus., index, notes. $£ 19.99$ (softcover).

CHITMAN, Karl, Kolokesa U Māhina-Tuai and Damian Skinner (eds): Crafting Aotearoa: A Cultural History of Making in New Zealand and the Wider Moana Oceania. Wellington: Te Papa Press, 2020. 280 pp., biblio., illus., index, notes. NZ\$85.00 (cloth).

DAVIDSON, Janet: The Cook Voyages Encounters: The Cook Voyages Collections of Te Papa. Wellington: Te Papa Press, 2019. 464 pp., biblio., illus., index, notes. NZ\$65.00 (cloth).

HARRIS, Aroha: Te Ao Hurihuri: The Changing World, 1920-2014. Wellington: Bridget Williams Books, 2018. 174 pp., illus., index, notes. NZ\$59.99 (softcover).

KIRCH, Patrick Vinton and Clive Ruggles: Heiau, 'Āina, Lani: The Hawaiian Temple System in Ancient Kahikinui and Kaupō, Maui. Honolulu: University of Hawai'i Press, 2019. 361 pp., biblio., illus., index, tables. US\$75.00 (cloth).

O'MALLEY, Vincent: The New Zealand Wars: Ngā Pakanga o Aotearoa. Wellington: Bridget Williams Books, 2019. 272 pp., biblio., illus., notes. NZ\$39.99 (softcover).

SMITH, Ian: Pākehā Settlements in a Māori World: New Zealand Archaeology 1769-1860. Wellington: Bridget Williams Books, 2019. 328 pp., biblio., illus., index, notes. NZ\$59.99 (softcover).

* The inclusion of a publication in this list neither assumes nor precludes its subsequent review. 